\title{
ANALYSING ITALIAN REGIONAL PATTERNS IN GREEN ECONOMY AND CLIMATE CHANGE. CAN ITALY LEVERAGE ON EUROPE 2020 STRATEGY TO FACE SUSTAINABLE GROWTH CHALLENGES?
}

\author{
Francesco BONSINETTO ${ }^{1)}$, Enzo FALCO ${ }^{2)}$ \\ 1) University "Mediterranea" of Reggio Calabria, Italy \\ 2) Sapienza University of Rome, Italy
}

\begin{abstract}
European cities and regions are facing the crucial challenge of greening their economy towards more sustainable patterns. Politicians and policy-makers should promote new policies for sustainable growth including renewables, greenhouse gas emissions, energy efficiency and biodiversity. All of these aspects can be considered as a boost for local and regional economy. In this regard, European countries and regions can benefit from the Europe 2020 Strategy which is defined as Europe's blueprint for a smart, sustainable and inclusive future, providing a ten year roadmap for growth and jobs. EU2020S was designed as a European exit strategy from the global economic and financial crisis in view of new European economic governance. This study discusses the above issues regarding Italy and intends to provide some answers on the perspectives of the new EU2020S. It draws from a research project supported by ESPON, the S.I.E.S.T.A Project, focused on the territorial dimension of the EU2020S. Therefore, this paper aims at analyzing Italian regional patterns on climate change, green economy and energy within the context of EU2020S and at providing policy recommendations for better achieving the goals of the Strategy.
\end{abstract}

Key Words: green economy, energy, climate change, Europe 2020, Italy.

\section{Introduction}

Green economy is an emerging paradigm at the heart of the economic and political agenda of the majority of developed countries. The concept of green economy is directly related to climate change and energy efficiency that are environmental "problems" with clear political and social implications (Khor 2011). The sustainability question is gaining significance as a "global explosion" produced by the scarcity of vital resources (energy, land, water) and global warming appears to become more realistic and a crucial issue of growing interest among policy makers and economists after Rio +20 (Loorbach 2010, UNEP 2011). However, green economy is a complex concept that has not yet received an international consensus with scholars debating on the different interpretations and meanings of "green growth". Between those who argued that green growth is the best potential way out of the financial crisis and onto a sustainability paradigm (OECD 2009, Makower and Pike 2009, Bosselmann et al. 2012) and others who consider it just an oxymoron or paradox (Ulrich 2012, Ploeg Van Der and Withagen 2013), it is a fact that even Europe has to face global challenges that impose strategic choices.

Europe is aware of the need to rethink the existing development model based on decades of resource intensive growth as well as to structurally change production patterns and consumption behaviours (EC 2010a). European Member States recently have decided to address these questions with a strong political response that can offer serious opportunities to 
enhance sustainability in a short time, shift towards green economy, address local challenges and respond to or even reverse damaging trends (EC 2011d). After the "Lisbon Agenda" experience, considered by many economists, policy makers and scientists a failed strategy (Sapir et al. 2003, Kok 2004, Zgajewski and Hajjar 2005), in 2010 the European Commission launched a new strategy called "Europe 2020" as a European exit strategy from the global economic and financial crisis to help European cities and regions to change the model of growth by shifting towards a low-carbon economy. This Europe's blueprint for a smart, sustainable and inclusive future is a ten year roadmap for growth and jobs and should improve territorial cohesion with structural sustainable reforms (EC 2010b).

In this context, Italy is a country that is struggling to plan a real transition to a sustainable and greener economy. As the findings reported in this work will demonstrate, Italian regions need a "transformational agenda" based on a long-term vision and consistent policies (from energy, transportation, sustainable agriculture to combating climate change, preserving biodiversity). Europe 2020 Strategy can be considered a crucial opportunity to make European regions and cities greener, smarter and inclusive. Can Italy leverage on this strategy to face sustainable growth challenges?

Drawing on the Espon Siesta Project "Spatial Indicators for a Europe 2020 Strategy Territorial Analysis", which has analyzed the territorial dimension of the EU2020S through the elaboration of selected indicators at different territorial levels, this paper seeks to contribute to the current debate by presenting the main results about regional patterns in Italy on climate change, green economy and energy within the context of EU2020S and to provide policy recommendations for better achieving the goals of the Strategy. This paper presents the results of the work carried out by the Unit of Reggio Calabria so as to provide a "picture" of the current situation of Italy relatively to the sustainable growth pillar. Particular attention will be paid to GHG emissions, energy intensity of the economy, and renewable energy sources, since it is believed that the EU2020 Strategy headline targets of $20 / 20 / 20$ can potentially have the wider impacts on the economy, cities, city users and behaviours of households and people in general. In conclusion, the importance of new policy measures concerning urban areas which are needed to achieve the sustainable growth pillar targets will also be stressed and highlighted.

\section{Materials and Methods}

The maps presented in this paper regard themes that have assumed great significance in the last decade such as climate change, global warming, green economy, energy efficiency. They are environmental issues with strong "economic value" because it's increasingly clear the importance of the linkage between ecological, economic and social dimensions in the growing discussion in light of the environmental global crisis. As far as the sustainable growth pillar is concerned, the EU2020S primarily envisages that the European economy should maintain its leadership and competitiveness in the world through the delivery of new green processes and technologies that allow climate change to be combated and energy efficiency to be achieved. Main actions should be directed to further develop and use low-carbon technologies and renewable sources of energy. The EU2020S acknowledges that such an approach will prevent environmental degradation, biodiversity loss and unsustainable use of resources.

Regarding the concepts expressed above, the EU2020S actually has focused its pillar "sustainable growth" on economic growth rather than on a sustainability concept widely conceived. In our study we highlighted that the concept of sustainable growth by the EU2020S is far from conceptually clear. 'Growth' and 'development' are concepts that have stimulated a long debate among different academic perspectives. Scholars such as Daly stated that 
"development" means qualitative improvements, particularly in resource efficiency, so that economic activities do not exceed the regenerative and absorptive capacities of the ecosystem. "Growth" means quantitative increase in the amount of energy and materials taken from the earth and processed through the economy, returning to the earth usually in the form of waste (Daly 1997). Other ones argued that 'sustainable' is usually referred to 'development' and not to 'growth' (Hopwood et al. 2005) though Ulhoi pointed out that the concept of sustainable development has become an empty catch phrase of contemporary environmentalism (Ulhoi and Madsen 1999) and Pearce argued that the sheer proliferation of definitions of sustainable development is evidence of its evanescence and contestability (Pearce et al. 1989). Several scholars argue that 'sustainable development' is a complex concept that indicates a lack of consistency in its interpretation and it is a contradiction in terms or an oxymoron that takes away from us any perspective of hope (Sharachchandra 1991, Meadows et al. 1992, Latouche 2004). On the other hand, not even the concept of "sustainable growth" is so coherent for some scholars as Daly and Townsend that have defined sustainable growth as an "impossibility theorem" that "when applied to the economy is a bad oxymoron - self-contradictory as prose, and unevocative as poetry" (Daly and Townsend 1993). Actually in the current debate sustainable growth is often used by policy and decision makers as synonym for sustainable development, probably due to a misunderstanding based on a superficial knowledge about the meaning of the sustainability concept.

However, the approach of Siesta project has been to consider both the economic dimension of sustainability as intended by the EU2020S and the ecological and environmental dimensions which cannot be underestimated in the evaluation of the performances and competitiveness of countries and regions. Within this complicated scientific framework, the Unit of Reggio Calabria decided to stress also environmental and ecological aspects to better understand the drivers of competitiveness and change. Indeed we dealt with the sustainable growth pillar through the identification of various indicators capable of measuring national and regional performances against the objectives of the pillar itself. Indicators were chosen by taking in consideration the EU2020s headline targets (20\% reduction of GHG, $20 \%$ increase of RES, $20 \%$ reduction in energy consumption), the flagship initiative "Resource Efficient Europe" and other targets indirectly related to the EU2020S which express performances of industries with high energy spending, commuting, municipal waste collection, waste water treatment, protected areas under Natura 2000 and biodiversity loss. These indicators have been also graphically represented within 17 maps and produced with a clear link with the EU2020S in order to make conceptual sense within the Project as a whole.

In the context of the ESPON SIESTA Project, over 50 indicators have been elaborated, updated and analysed at different territorial levels, NUTS-0, NUTS-2 and NUTS-3, in order to determine a clear territorial picture of the EU-27 within the three pillars Sustainable Growth, Smart Growth and Inclusive Growth of the Europe 2020 Strategy. Indicators have been selected and data gathered with regard to many sectors ranging from regional GDP to energy intensity of the economy, waste treatment, RES, commuting, ICT investment, education, employment, poverty and exclusion and many more. It must be said that there were problems because of the general lack of environmental data at regional level and the controversial inclusion of aspects of economic growth under the umbrella of "sustainable growth". Secondly, and as there is no data on renewable energies at the regional level, it has been thought as useful to consider the potentials of wind energy and solar energy, as they may offer "future possibilities" in this respect; these data has been downloaded through ESPON 2013 DB, coming from ReRisk Project. Thirdly, for measuring sustainable development in relation to curbing greenhouse gas emissions, it is essential to take into account the transport sector and, in this respect, measurements on congestion have been introduced at NUTS2 level and a 
particular indicator available at URBAN AUDIT (EUROSTAT) on commuting. SIESTA Project has systematically tried to develop the work at the larger scale, that is, NUTS 3 and urban areas, but only when this is possible in terms of data availability. This means that, when data is not available for NUTS3 or urban areas, then NUTS2 scale is used and, in some exceptional cases, NUTS1 or NUTS0.

\section{Results and Discussion}

The transition to an energy efficiency and green economy

By now there is strong evidence that human activities are consuming many natural resources and are causing global warming and changes in the climate system (Barnosky et al. 2012). The scientific community also warned that human activities need to be reconsidered in a way which will allow the regenerative capacity of these assets to function (IPPC Report 2013). For instance, emissions and other greenhouse gases (GHG) will need to be cut in order to avoid further devastating effects of climate change (Arnell et al. 2013).

European countries agree that reversing climate change and achieving energy efficiency are the overall policy priorities of the coming decades and that the gradual transformation towards a resource-efficient and low-carbon economy will be the decisive trend of the future. Clearly, these topics have an important economic relevance in as much as a cleaner environment and greener cities are costly (Butter and Verbruggen 1994, Meyer 1995, Brock and Taylor 2005). According to scientific evidence that shows an acceleration of climate change patterns and a deepening of the climate crisis (EWEA 2011), the EU as a whole must restructure strongly its economy and reduce domestic greenhouse gas emissions by $25 \%-40 \%$ identified by the IPCC to give us a $50 \%$ chance of avoiding the $2^{\circ} \mathrm{C}$ temperature rise (IPCC 2007). So changing our current patterns of resource use relying mostly on renewables that is a sector in strong expansion (IEA Report 2012) and the transition towards the green economy is not a choice but a necessity (Whitehead 2007). Europe 2020 and its Roadmap for resource efficient Europe provide clear guidance (EC 2011c).

Addressing environmental concerns directly addresses economic problems. As it is known, Europe is facing a great financial crisis and problems of (urban) unsustainable development. By addressing climate change mitigation through the pursuit of sustainability pathways, it is increasingly necessary to build even stronger links between ecology and economy encouraging an integrated global approach that considers not only emissions reductions, resources efficiency and climate change policies, but also the drivers of unsustainable patterns of production and consumption (Edwards 2010). Moreover the path to more sustainable European cities and regions can generate an economic opportunity boosting, among other things, growth and job creation (Zysman and Huberty 2012).

A green transition of Europe as a whole should be exactly the way to recover from the financial crisis because green economy is a challenging opportunity for the European countries (EC 2011d). Regions and cities see the challenge as an opportunity to take our societies out of the global economic crisis transformed into more sustainable, low carbon, less resource intense and inclusive communities; as well as to exchange experiences and increase regional skills and competiveness towards a green economy. In this context, regions are particularly well placed for identifying the needs and the strengths of our societies in tackling climate change. Clearly, the overarching concept of a green economy recognizes that ecosystems, the economy and human well-being, and the related types of capital they represent, are intrinsically linked. At the core of these are the continued challenges of improving resource efficiency whilst 
ensuring ecosystem resilience in the natural systems that sustain us (EC 2010c).

Our study show how Italy, and more in general all European countries, if really wants to become greener, more sustainable and equity and addresses new global challenges in a coherent, consistent and efficient manner, needs to act collectively against the climate change and for building a green economy (The Lisbon Treaty 2009). As the maps showed, there are more advanced countries in renewable energy consumption such as Norway and Sweden or in municipal waste collection such as the old MS, or in reduction of GHG emissions such as United Kingdom and Hungary, and on other hand, countries that have to make an effort to improve their situation (such as the new MS and candidate members). The more "organized" countries should help other countries with knowledge and technology transfer as well as various governance models. So the goal of sustainable growth can only be achieved with a concerted effort to improve the current situation. Just with a collective action there will be possible to fight climate change and change negative trends.

We believe that mostly these issues have to be addressed at regional and local levels. Regional development is usually considered very important for dealing with climate change, green economy and energy issues (Espon Climate 2011, OECD 2009, Stern 2006). Regional characteristics directly determine the extent to which EU regions can produce renewable energy. For example, the production of solar and wind energy is highly location-dependent. Coastal regions tend to have a high wind energy potential, while southern regions with more sunny days have more potential for solar energy. Moving renewable energy between regions with a high potential to regions with a high demand will require the development of better and more intelligent energy networks. In addition, regions and cities can reduce greenhouse gas emissions by promoting cleaner modes of public transport and shifting to more sustainable modes of transport. Initiatives to promote cleaner and more efficient transport have to adapt to the local context, focusing on the infrastructure in regions where it is still lacking while targeting the attractiveness of sustainable transport modes and demand management in other regions. Regions and cities can play a prominent role in fostering energy efficiency. This is particularly true in regards to buildings, where actions must adapt to the local context and climate. These actions are likely to be different between urban and rural areas or between places with old versus more recent buildings.

Regarding these points, Europe is strongly working to change the development model and move toward a more equal economy, balanced and respectful of a heritage to be passed on to future generations. Mostly the fight to tackle climate change, to improve resilience and to achieve the sustainable energy transition will be won or lost in cities because they generate around $75 \%$ of all $\mathrm{CO}_{2}$ emissions because they host a high share of the population and an even higher share of economic activities, which is why cities need to be at the forefront of the fight against climate change (Register 2006). In addition, in Europe, approximately 375 million people live in urban regions and around $56 \%$ of the urban population - or $38 \%$ of Europe's population as a whole - lives in cities and towns of between 5.000 and 100.000 inhabitants (Committee of the Regions 2012). Consequently, it is evident that sustainable growth and climate change have a strong urban characterization because just here in the cities they are actually the most apparent in the everyday life, with stark impacts involving health, job, infrastructure, business and food. In this sense, cities are competing with each other because depend highly on other regions in Europe and beyond. So the city level has to be a major focus of attention if we want to address seriously the problems of environmental deterioration, global warming and climate change. Urban planning implications are reflected in buildings, streets and community design for more environmentally sustainable cities. Spatial planning is generally regarded to be responsible and capable to reduce regional vulnerability and to develop climate 
mitigation and adaptation capacities against the impacts of climate change (Stern 2006, IPCC 2007). In addition, it is the right tool to shape local communities' future and make cities livable and resilient. The importance of addressing these problems by the local level is stressed also by the EU White Paper "Adapting to climate change: Towards a European framework for action" (EC 2009) when stated that "a more strategic and long-term approach to spatial planning will be necessary, both on land and on marine areas, including in transport, regional development, industry, tourism and energy policies".

Regional trends in Greenhouse Gas (GHG) emissions and climate change related issues

The reduction of GHG emissions is clearly the most important environmental issue intrinsically linked with the way we live. Climate change is high on the international political agenda as the scientific proof of the human impact on climate becomes stronger (IPCC 2007a, 2007b) and as society is becoming aware of its potential consequences. One of the major goals of the EU2020S is to help the EU prosper in a low-carbon world and in a more competitive economy, preventing environmental degradation and biodiversity loss. This includes the reduction of GHG emissions, the promotion of renewable energies and more efficient energy supply systems. In this section we discuss the energy intensity of the economy indicator very briefly, although data are not available at the regional level, as one of the most important measures to reduce GHG emission and the estimated greenhouse gas emissions indicator elaborated within the SIESTA project as a way to highlight the trajectory that the Italian regions are currently following.

The energy intensity of the economy is a key indicator which measures the energy efficiency of a country's economy. Therefore, it is one of the most effective ways to meet energy needs, reduce energy costs and lower greenhouse gas emissions. A reduced and efficient consumption of energy is of paramount importance to achieve climate change targets and lower impacts on the environment. Italy as a whole is performing extremely well with regard to this indicator showing the forth lowest ratio of Kilograms of oil per 1000 Euros of GDP as in Table 1 below.

5 EU-27 Member States (MS) with lower ratios of energy intensity of

Table 1 the economy (2010 year)

\begin{tabular}{|c|c|}
\hline \multicolumn{2}{|c|}{ The five EU Member States with the lower ratio } \\
\hline Country & Ratio \\
\hline Denmark & 105.19 \\
\hline United Kingdom & 112.39 \\
\hline Ireland & 112.65 \\
\hline Italy & 140.84 \\
\hline Austria & 142.41 \\
\hline
\end{tabular}

The ratio is expressed in Kilograms of oil equivalent per 1000 EUR of GDP. Source: Siesta Project elaboration

The energy intensity of the economy indicator should guide action of all Member States in achieving and delivering greater energy efficiency. The geographical pattern of the energy intensity indicator shows characteristics which are not surprising, highlighting a marked division between Western and Eastern Europe. New Member States such as Bulgaria, Romania and Estonia have very high energy intensity ratios, showing great potentials for large improvements 
continuing on the paths of steady reduction (Fig. 1).

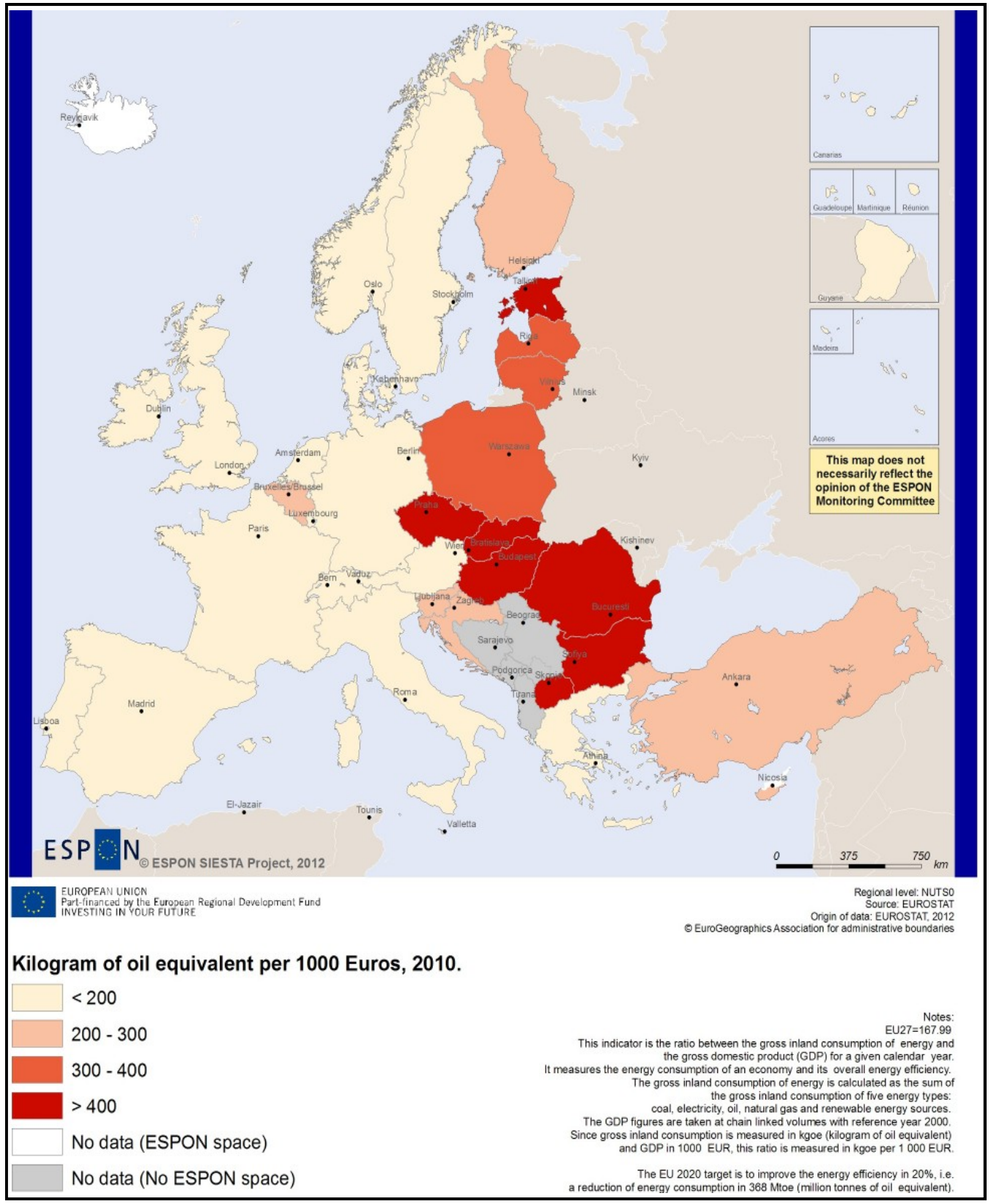

Fig. 1 - Energy intensity of the national economy represented as gross inland consumption of energy divided by GDP, 2010

Source: ESPON Siesta 
Good performances are reported by several old Member States; above all, Denmark, the UK, Italy, Austria and Ireland, which show ratios close to the worldwide lowest energy intensity economy of Japan, and at the same time potential to reduce the gap from Japan itself. The energy sector could deliver important economic and environmental benefits with the creation of new jobs and reduction of energy dependency from imports of energy and raw materials. Greater energy security for the Union will be delivered if the target of $20 \%$ increase in energy efficiency is delivered.

Italy should place strong emphasis on this indicator due to the high imports of energy from other countries which make our country the first importer of energy from foreign sources of all European countries with a share of $14 \%$ of its total energy consumption (Terna 2013). A higher energy efficiency would therefore result in an economic benefit especially for the industrial sector and energy-intensive industries with the whole economy that would benefit from a steady and considerable reduction in costs and consequently in prices of end products. Moreover, as already highlighted within the two flagships "Resource-efficient Europe" and "An industrial policy for the globalisation era", "meeting our energy goals could result in $€ 60$ billion less in oil and gas imports by 2020" and renewable energy sources targets coupled with energy efficiency targets could result in over 1 million new jobs (EC 2010c: 13).

The other indicator whose discussion is of extreme importance in this section is the regional estimation of GHG emissions indicator. Such indicator was derived from different sources such as Eurostat "Greenhouse gas emission" and UNFCCC "National greenhouse gas inventory data for the period 1990-2009" and calculated by the SIESTA team by using the methodology provided by the ESPON Climate research project which allows the expression of regional GHG emissions from national level data using regional population and regional gross added value data from EUROSTAT. This indicator shows annual total aggregate GHG emissions excluding emissions/removals from land use, land-use change and forestry (LULUCF) over the period 1990-2009. It does not include emissions from international aviation and international maritime transport.

Regional estimates of GHG emissions at NUTS2 and NUTS3 level are becoming increasingly significant to understand the contribution of cities to global climate change. Regions have different opportunities to embed adaptation and mitigation into their strategies, decreasing GHG emissions and adjusting their socio-economic systems to a low carbon economy. The analysis of the regional differences serves several purposes such as identifying the greatest sources of emissions within a particular region; providing a basis for developing specific tools, and contributing to trend analysis in the establishment of future goals and targets. Regional distribution of GHG emissions across Europe is quite heterogeneous (Espon Siesta Project, Atlas, 2013). Figure 2 and table 2 clearly show a division (equally spread in the new and in the old EU Member States) between metropolitan and urban areas such as Madrid, Barcelona, Milan, Rome, Paris, Berlin, and Bucharest and rural, low-density and depopulated areas. This demonstrates that GHG emissions have an important urban and regional dimension. The main metropolitan areas generate the highest GHG emissions. This is explained by the fact that one of the variables that is taken into account in the model for regionalisation of GHG emissions is the population. However, while literature states that livestock is substantial for GHG emissions, this has not been accounted for by the model. Logically, it would increase the GHG emissions contribution of some rural areas specialised in intensive primary industries. In any case, previous research has quantified that cities generate around $75 \%$ of all $\mathrm{CO} 2$ emissions, implying that challenges in this respect are territorially concentrated in these areas but may possibly affect other specific rural areas (Register 2006). 

2020 Strategy to Face Sustainable Growth Challenges ?

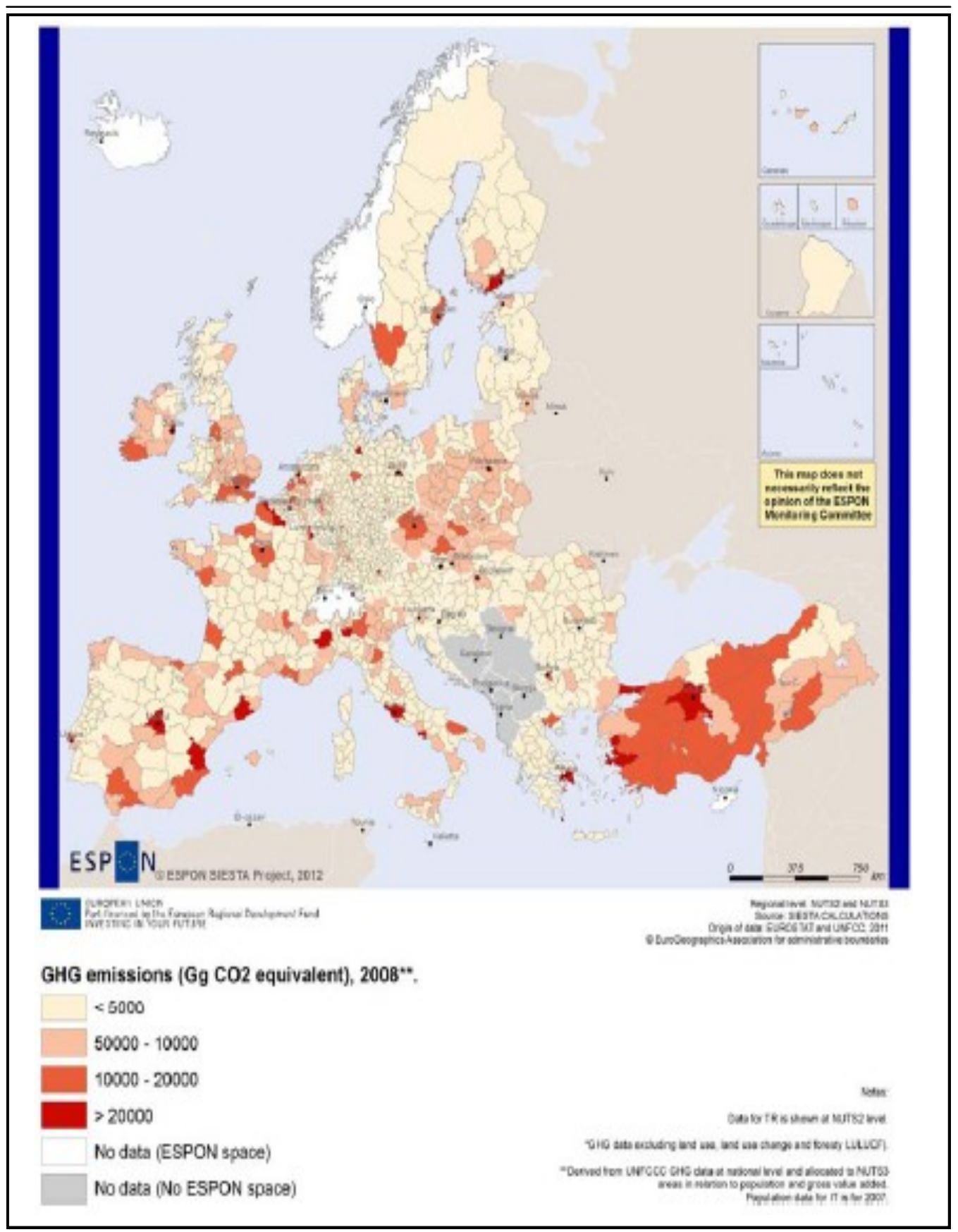

Fig. 2 - Estimated regional GHG emissions excluding LULUCF, 2008 Source: ESPON Siesta elaboration 
The 15 NUTS-3 Regions with the highest share of GHG emissions in 2008

\begin{tabular}{|l|l|c|}
\hline Member States & \multicolumn{1}{|c|}{ Region } & $\begin{array}{c}\text { Regional estimates GHG emissions } \\
\text { (exc. LULUCF) }\end{array}$ \\
\hline TR100 & Istanbul province & 83261.52 \\
\hline ES300 & Madrid & 62774.90 \\
\hline ES511 & Barcelona & 51464.55 \\
\hline GR300 & ATTIKń (Attiki) & 50252.12 \\
\hline ITC45 & Milan & 43489.98 \\
\hline ITE43 & Rome & 41666.27 \\
\hline DE300 & Berlin & 37907.74 \\
\hline PL127 & Miasto Warszawa & 34778.67 \\
\hline FR101 & Paris & 33730.21 \\
\hline DE600 & Hamburg & 27507.19 \\
\hline TR510 & Ankara & 27192.39 \\
\hline CZ010 & Hlavní město Praha & 27085.04 \\
\hline RO321 & Bucureşti & 23806.07 \\
\hline ITF33 & Naples & 22969.91 \\
\hline FR105 & Hauts-de-Seine & 22651.20 \\
\hline Country Code: CZ Czech Republic; DE & Germany; ES Spain; FR France; GR Greece; \\
IT Italy; MT Malta; PL Poland; RO Romania; TR Turkey
\end{tabular}

Source: Siesta Project elaboration

Data on Italian regions confirm this hypothesis (Fig. 3). The metropolitan areas of Milan, Rome and Naples are the three provinces with the highest levels of emissions of GHG. Other areas such as the industrialized North West and North East of the country with regions such as Piemonte and Veneto show high levels of GHG emissions. In the south of the country, apart from the area of Naples which is the third metropolitan area by population size, the provinces that show high levels of emissions coincide with the metropolitan areas of Bari, Palermo, Salerno and Catania. Among the 20 provinces that show the highest levels of emissions, only five are in the South. Table 3 shows how emissions are strongly related to population size and also to the industrial activity as in most of the northern regions.

The area of Taranto, where the ILVA industrial site that came to the fore in national as well as international news reports is located, does not show high levels of GHG emissions. However, recent data and reports on such area in 2012 and 2013 show high concentration of pollutants in the city of Taranto with consequently high risks for the public health (Kington 2012, Meichtry 2012).

In conclusion, because of the urban and regional dimension of GHG emissions, regional strategies for mitigating climate change are highly recommendable. Considering that metropolitan areas show high concentrations of GHG emissions, it is clear that particular urban strategies should be undertaken. All of this has direct implications for spatial and urban planning with the need to reduce sprawl and to favour a compact urban model. More efforts need to be undertaken by the majority of member states to increase energy efficiency and renewable energy development in order to decrease the amount of fuel burned in power plants, other industries, commercial buildings and households. The implementation of policy guidelines 

2020 Strategy to Face Sustainable Growth Challenges?

on GHG reduction should take into account not only the state level, but also the local and regional scales. Changes at the local and regional spheres, for instance focusing on land use planning and management, actively contribute to the overarching aims.

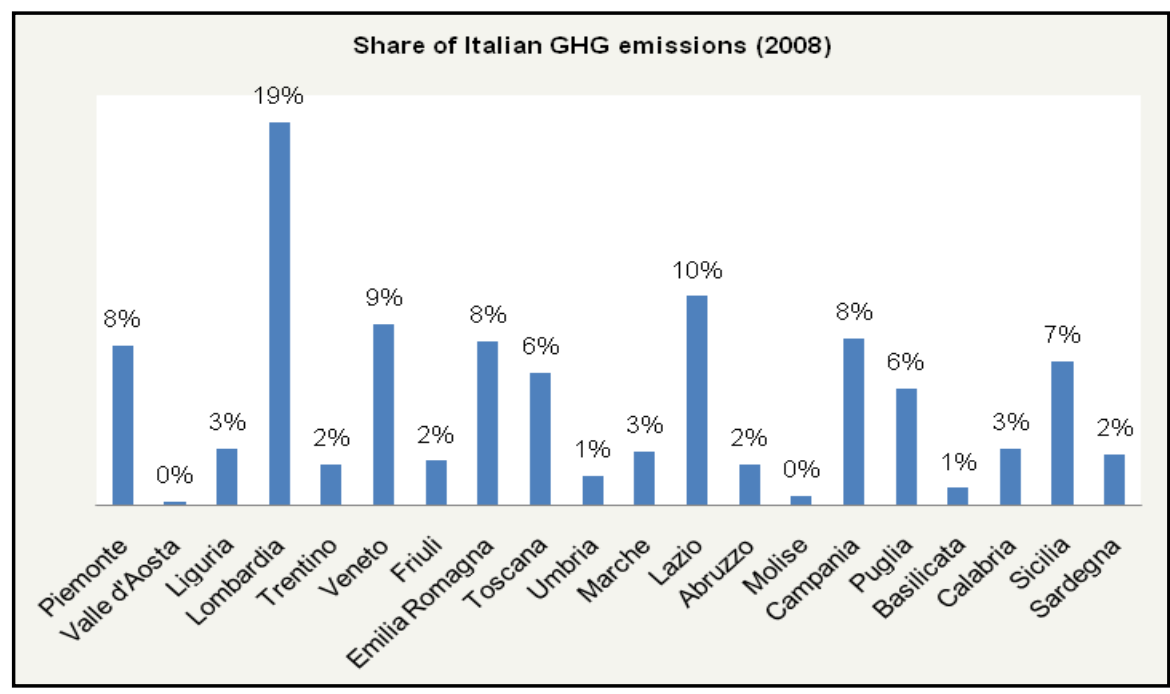

Fig. 3 - Greenhouse Gas Emissions by Region estimates in Italy (2008 Year) Source: SIESTA Team elaboration

Table 3

GHG emissions by for Italian Provinces in 2008

\begin{tabular}{|l|r|r|r|}
\hline \multicolumn{1}{|c|}{ Provinces } & Emissions & Population & Rank by population \\
\hline Milano & 43,490 & $3,075,083$ & 2 \\
\hline Roma & 41,666 & $4,039,813$ & 1 \\
\hline Napoli & 22,970 & $3,055,339$ & 3 \\
\hline Torino & 21,718 & $2,254,720$ & 4 \\
\hline Bari & 12,432 & $1,246,297$ & 5 \\
\hline Brescia & 12,239 & $1,247,192$ & 6 \\
\hline Bergamo & 10,832 & $1,094,062$ & 8 \\
\hline Bologna & 10,135 & 990,681 & 11 \\
\hline Firenze & 9,721 & 987,354 & 12 \\
\hline Palermo & 9,488 & $1,243,638$ & 9 \\
\hline Padova & 8,959 & 927,848 & 13 \\
\hline Verona & 8,834 & 907,352 & 15 \\
\hline Salerno & 8,518 & $1,093,453$ & 9 \\
\hline Vicenza & 8,501 & 865,421 & 18 \\
\hline Varese & 8,496 & 876,964 & 17 \\
\hline Treviso & 8,486 & 881,245 & 16 \\
\hline Venezia & 8,328 & 847,983 & 21 \\
\hline Genova & 8,250 & 851,283 & 19 \\
\hline Catania & 8,067 & $1,077,113$ & 10 \\
\hline Modena & 7,078 & 688.376 & 24 \\
\hline
\end{tabular}

Source: SIESTA Team Elaboration 
Regional trends in renewable energy production and consumption

Renewable energy is a crucial sector for a transition towards a low carbon economy. The use of renewable energy sources is a key element of an energy policy able to reduce dependence on fuel, emissions from carbon sources and to decouple energy costs from oil prices. Also, the renewable energy sector offers interesting perspectives for the development of new technologies and for new employment opportunities. As the "Energy 2020 Strategy" points out, it is estimated that achieving the EU target of $20 \%$ of final energy consumption by renewables by 2020 could provide about 410,000 additional jobs, the majority of which close to where the investments are made (EC 2010a: 9). Renewable energy is defined as any energy source that derives directly or indirectly from natural processes related to sunlight, heat stored in the earth or gravitational forces and that is constantly, naturally replenished (IEA 2011). Renewable energy includes hydroelectricity, biomass, wind, solar, tidal and geothermal energies.

The independent 2010 Renewable Energy Attractiveness Index indicates that US and China cities represent at the moment the best investment opportunities for renewable energy. New stimulus is needed; more than ever EU leadership is called upon to address these challenges (EC 2010a). At the national level the North Baltic Sea region is the geographical area that has the greatest development of renewable energy sources. The highest share of consumption from renewable sources was recorded in Norway with a $64.9 \%$, though outside the EU-27, followed by Sweden with a $47.3 \%$, Latvia $34.3 \%$ and Finland $30.3 \%$. There are another three states above the EU2020S target in different parts of the continent (Austria, Portugal and Romania).

Table 4

Share of RES in final electricity consumption by region (2010 Year)

\begin{tabular}{|l|r|l|r|}
\hline \multicolumn{1}{|c|}{ Region } & $\begin{array}{c}\text { Share of RES in final } \\
\text { electricity consumption } \\
(\%)\end{array}$ & Region & $\begin{array}{c}\text { Share of RES in final } \\
\text { electricity consumption } \\
(\%)\end{array}$ \\
\hline Piemonte & 26.0 & Umbria & 37.4 \\
\hline Valle d'Aosta & 251.4 & Marche & 10.9 \\
\hline Lombardia & 19.1 & Lazio & 7.4 \\
\hline Liguria & 5.4 & Abruzzo & 34.0 \\
\hline Bolzano & 178.4 & Molise & 59.1 \\
\hline Trento & 119.9 & Campania & 15.1 \\
\hline Veneto & 15.8 & Puglia & 17.8 \\
\hline Friuli-Venezia Giulia & 22.0 & Basilicata & 37.4 \\
\hline Emilia-Romagna & 9.9 & Calabria & 53.9 \\
\hline Toscana & 31.5 & Sicilia & 11.0 \\
\hline & & Sardegna & 15.9 \\
\hline
\end{tabular}

Source: ISTAT (noi-italia.istat.it)

Italy in 2009 showed a share of $8.9 \%$ (ESPON Siesta, 2013). However, data gathered specifically for this paper from the Italian National Institute for Statistics (ISTAT) show performances at the regional level as of 2010 that do not vary considerably across regions. On average, excluding the autonomous region of Valle d'Aosta and the provinces of Bolzano and Trento, the southern regions' shares of RES in final electricity consumption are on the same level as the northern regions' (Table 4). However, things change considerably if renewable energy production by source is taken into consideration. Figure 4 below shows the level of RES 
production by source for all of the regions. It is soon clear that the gap between the two areas is determined by investments in the technologies that are able to exploit natural sources for energy production.

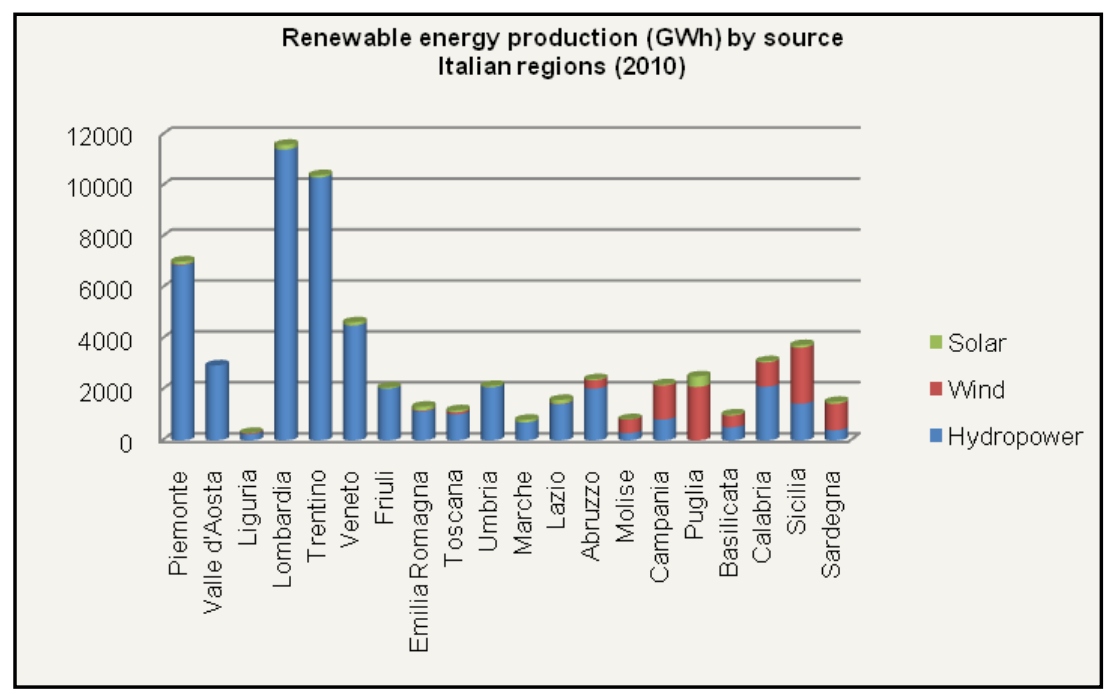

Fig. 4 - Renewable energy production by source and region in Italy (2010 Year) Source: Gestore Servizi Energetici 2010 (http://www.gse.it/en/Pages/default.aspx)

Figures 5 and 6 show the potential for electricity production from wind power stations and photovoltaic panels. Wind power potential is derived from ESPON ReRisk final report "Production potential of wind power station among NUTS level 2 regions". This indicator identifies those regions in Europe which have the highest potential for producing electricity from on-shore wind power. As Figure 5 shows, wind power potential for northern as well as southern regions falls within the same class. However, surprisingly enough, despite of this, Figure 6 shows that electricity production from wind is much more developed in the South. The same cannot be said for solar PV panels production. Even though the potential for southern regions is obviously and visibly greater (Fig. 6), the production from this source does not differ considerably, leaving large unexploited potential for production from solar PV panels which could make southern regions more competitive, create new jobs and reduce the gap from the national target of $18.7 \%$ of total energy produced from RES.

\section{EUROPE 2020 Strategy challenges and regional disparities}

The discussion of specific indicators in the previous sections has showed how the Italian regions have different patterns in the production of energy from RES and how there is ample margin of improvement which would benefit both the economy and the environment. Efforts should be focused on reducing energy dependency form other countries, and this can be done by leveraging on two important sectors such as energy efficiency and production from RES. With regard to the latter, the southern regions appear to have invested less in such sector, especially in the solar technology which could contribute a great deal to increase energy production from renewable sources. However, this is not the only sector/indicator where southern regions are under-performing if compared to the regions of the north of Italy. If other indicators are taken into consideration, such as urban waste water treatment capacity (Map 
2.24 of the SIESTA Atlas), and more essentially economic indicators such as regional unemployment rate (Map 4.5), regional population at risk of poverty (Map 4.16) and regional disposable income (Map 4.18), the situation does not change and the gap gets even wider.

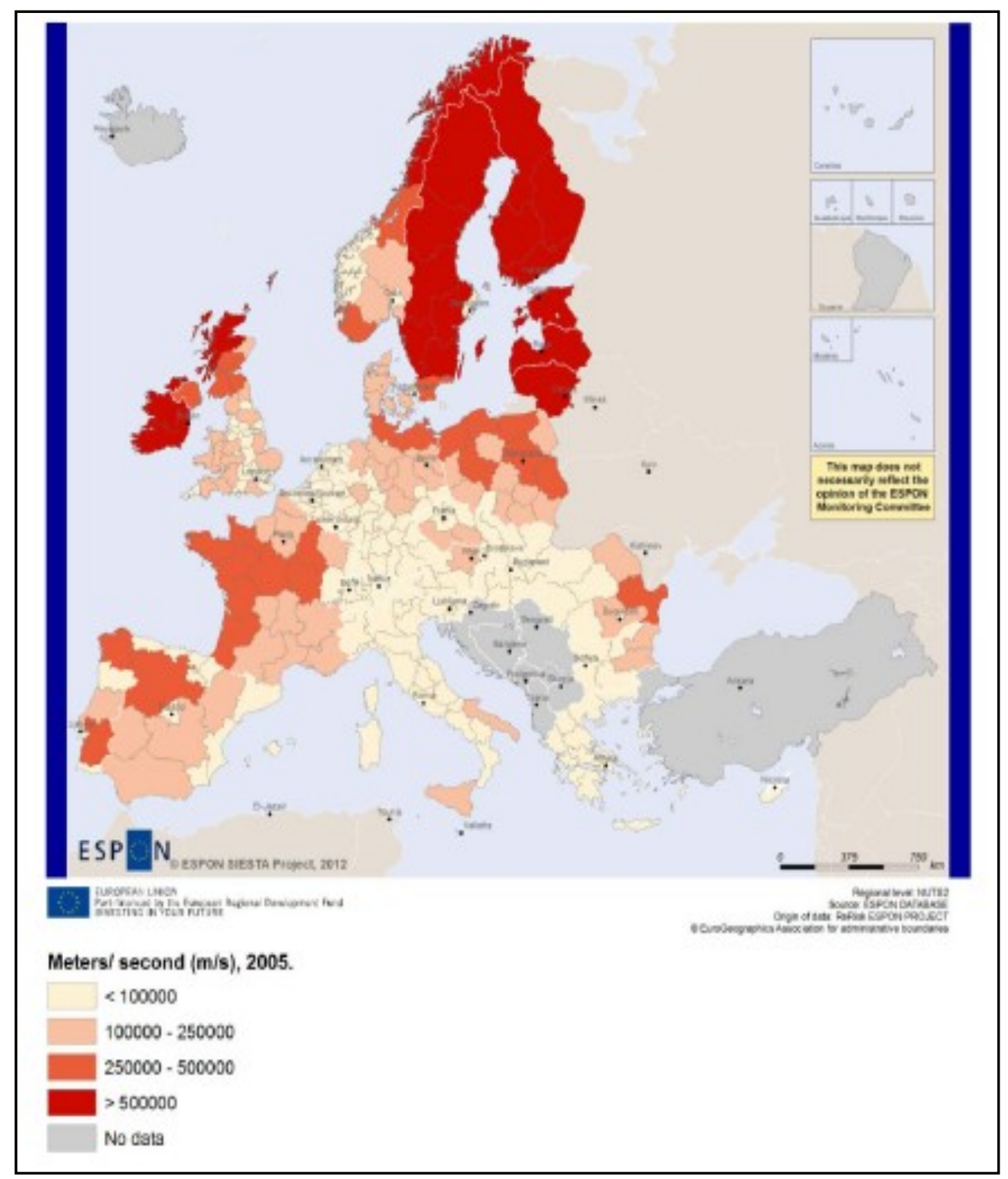

Fig. 5 - Potential for electricity production

from wind power stations represented in meters/second, 2005

Source: ESPON Siesta elaboration 


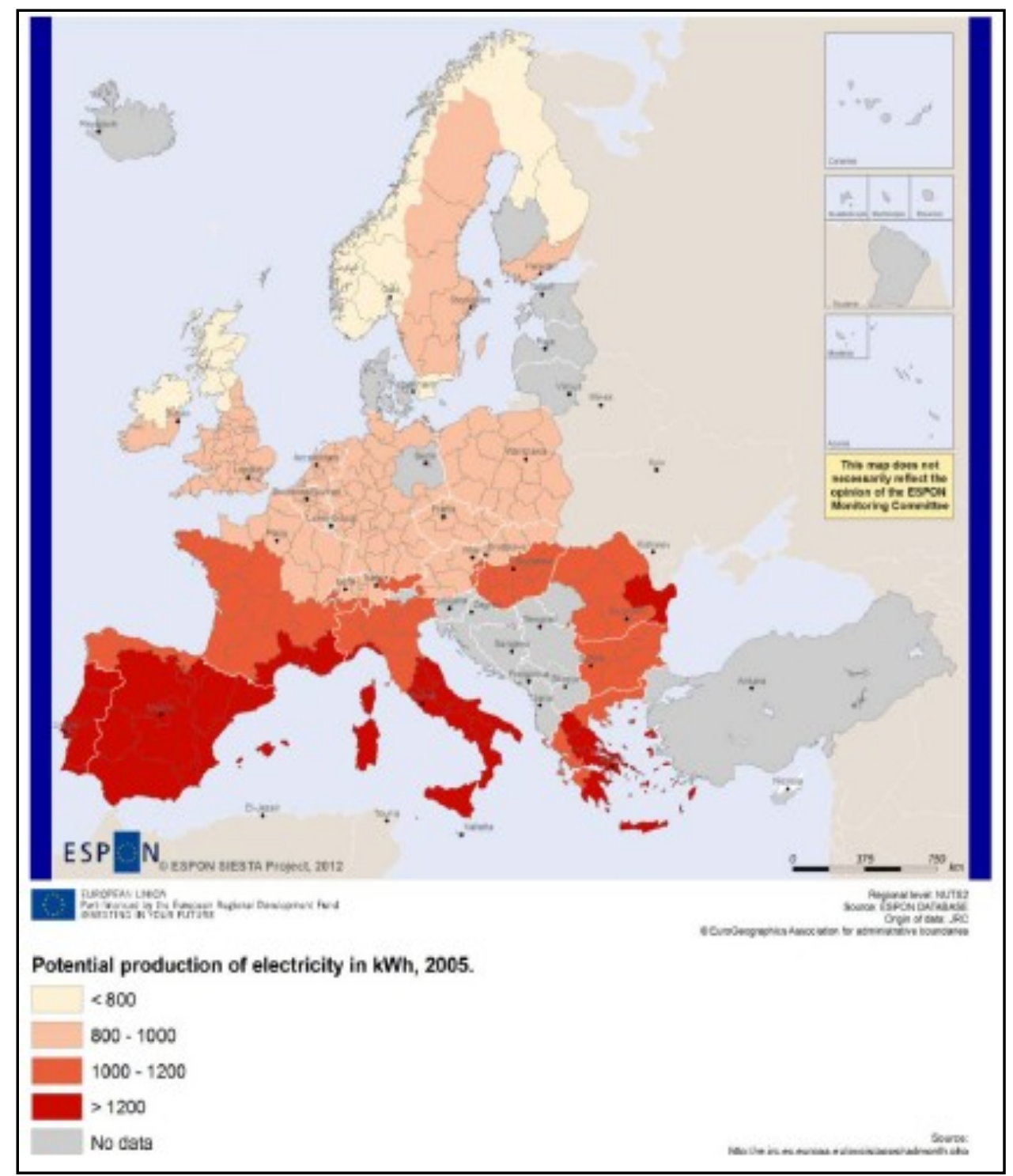

Fig. 6 - Potential for electricity production from photovoltaic panels represented in KWh, 2005

Source: ESPON Siesta elaboration

The south regions are performing poorly compared to the northern regions and there is a great need to take action in order to reverse current trends. The aggregate SIESTA index developed within the framework of the SIESTA project takes into consideration the entire eight headline targets of the EU20202 Strategy and measures the distance of regions from the achievement of the target. This indicator shows marked disparities between the south and the north and in 
general between all regions of Europe. A region would score 100 if it had reached all eight targets, while a region farthest away from all eight targets would score $0^{1)}$. The SIESTA project, with specific reference to the EU2020S and its policies and targets, has been able to highlight those sectors where most efforts should be placed in order to improve the current situation. The whole of Italy can benefit from targeted measures which, while creating job opportunities, could at the same time reduce greenhouse gas emission and increase energy efficiency. The main actions should therefore be aimed to achieve mixed targets in several sectors of the economy rather than focus only on job creation or on increasing production of renewable energy sources.

Figure 7 (Maps 5.1 of the SIESTA Atlas) shows that, all across Europe, all top positions in the achievement of the regional EU2020S aggregate index for 2009-2010 are represented by Scandinavian regions, plus Southern Germany, several French regions and South England (North of London and Hampshire). The divide for Italy is clearly visible and highlights disparities between the south and the north of the country. Such disparities and imbalances derive especially from indicators such as people at risk of poverty, early school leavers and unemployment rate. Figure 7 clearly shows that the worst performing regions are all the southern regions which have an index lower than 50 . All other regions score better and fall within the two classes $50-60$ or $60-70$, with the best performing regions equally distributed between Middle Italy and Northern Italy. In general, this Figure shows a general gap between Italy and the most developed regions of Scandinavia, Britain, France and Germany, meaning that there is margin of improvement. Designing specific policies that will contribute to meeting the EU2020S targets would certainly determine a strong improvement in the performances of the Italian regions.

\section{Conclusions and policy recommendations}

This paper, by building upon the results and outcomes of the SIESTA Project, has focused on the trajectories and trends of Italy and especially of the Italian regions with regard to fundamental indicators for climate change and sustainability-related performances such as energy efficiency, renewable energy sources and regional greenhouse gas emissions. The results highlight that there is great potential for the improvement of regional performances even in sectors such as energy efficiency of the economy where current Italian's performances are among the top European States. Whereas, as far as greenhouse gas emissions and energy production from RES are concerned performances can be greatly improved. The former, by acting and taking action mostly at local and regional level since emissions appear to be extremely related to metropolitan areas with the largest population. Acting on household behaviours, public transport improvements in large cities since, transport accounts for about one quarter of all EU GHG, and new freight transport policies, and new and more efficient buildings could deliver greater improvements than expected, not only relatively to cutting emissions but also with regard to energy efficiency. Green economy and renewable energy can stimulate job creation, new technologies and increased trade. Moreover, as seen, there is also a great potential for solar PV enhancement especially for the southern regions. Investment in this sectors as well as measures to constantly increase energy efficiency have the potential to reduce energy dependency of Italy resulting in lower costs of end products which coupled with potentially cheaper freight transport would bear extremely positive results.

1) However, it should be kept in mind that data are available only at the national level for the three indicators that particularly interest us in this paper (20/20/20 Targets), and that for another one (people at risk of poverty or social exclusion) the scale at which data are available changes depending on the country. 


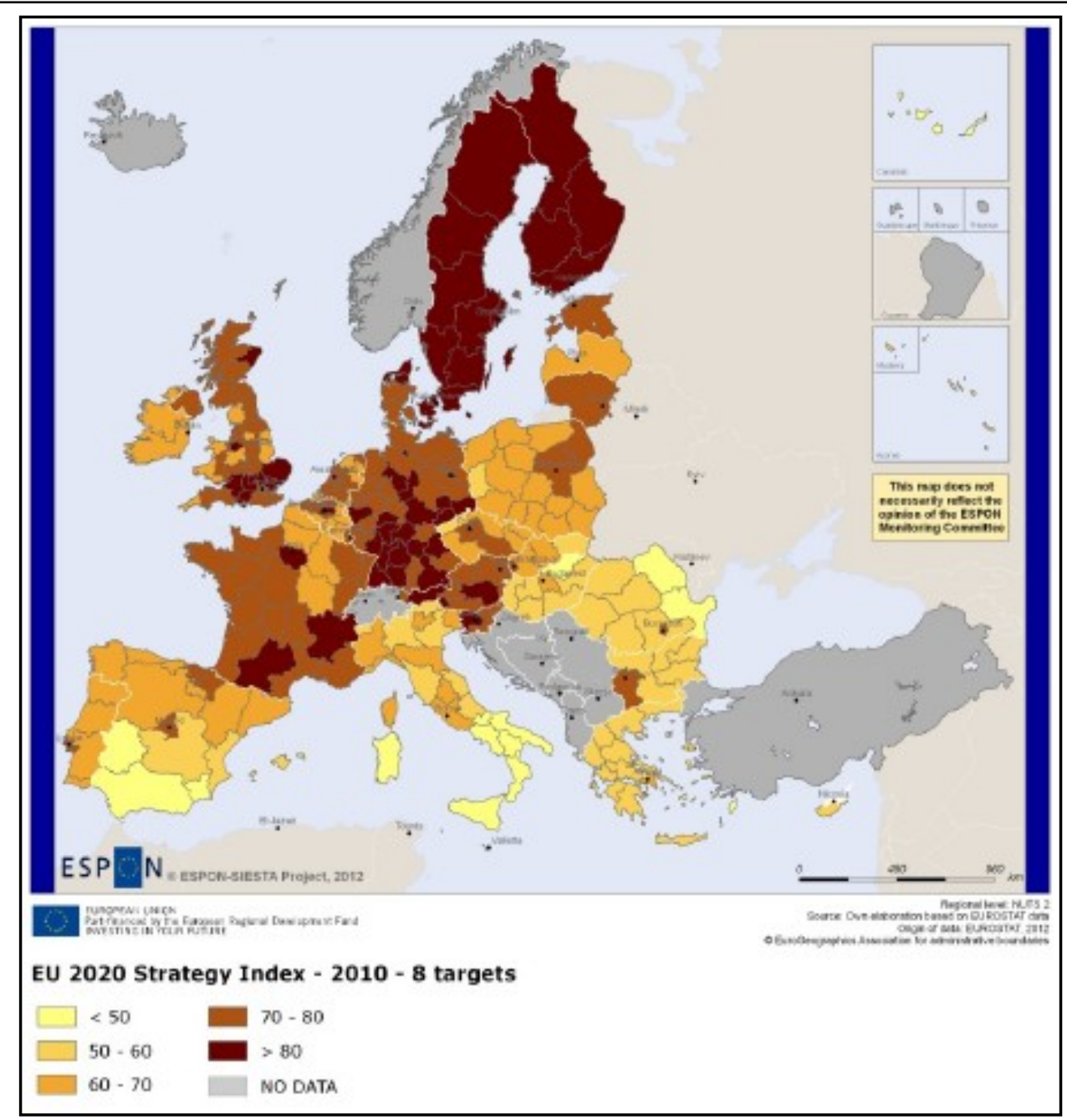

Fig. 7 - Siesta Aggregate Index Source: ESPON Siesta elaboration

However, in order to determine a shift towards a greener and more sustainable economy, there is also the necessity to face the disparities and imbalances between the North and the South of the country, which generally concern several sectors from energy to education, ICT, waste and essentially economic indicators such as disposable income, unemployment rate and people at risk of poverty. Like other European countries, Italy is suffering a complex period of financial crisis that does not encourage investments on renewables and energy efficiency. Apart from this, Italy has a long (negative) tradition as Member State with relatively low absorption rate in structural funds. Italy needs to implement new policies in order to avoid past mistakes.

Is Italy ready to take advantage of the upcoming 2014-2020 EU structural funds as well as the Europe 2020 Strategy? Our point of view is that Italy should coordinate better the governance 
between the State and Regions and raise awareness of the importance of all opportunities derived by EU2020S. The latter, as seen in this paper, could be a great strategy to improve territorial cohesion and regional disparities in smart, inclusive and sustainable growth, but without a regional policy rationale that rests on the application of industrial policy as a fulcrum for integrating the different components of the domain governance of Europe 2020, its objectives may not be realised (Budd 2013). The achievement of a (real) sustainable growth in Italy requires dynamic regional authorities, investments on R\&D, new policies based on strong links between development, production and sustainable consumption, timely and applicable solutions. All these components may be better integrated in developing an Italy's key strategy for the rest of the decade.

\section{Acknowledgements}

We would like to acknowledge all members of the SIESTA Project and specifically the Lead Partner, University of Santiago de Compostela in Spain, for its valuable support and guidance during all the phases of the project. The maps shown in this work were elaborated within the SIESTA project and were kindly provided by the Lead Partner. SIESTA - Spatial Indicators for a "Europe 2020 Strategy Territorial Analysis (www.siestaproject.eu) is a project financed by the European Union in the framework of ESPON, the European Observation Network for Territorial Development and Cohesion. The project is leaded by the University of Santiago de Compostela (Spain) and involves other seven academic and research partners coming from six different European countries: France, Greece, Ireland, Italy, Poland and Romania. As Project Partner no. 4 (University Mediterranea of Reggio Calabria, Italy), we had in charge a subsection about climate change, green economy and energy under the umbrella of the "sustainable growth" pillar of Europe 2020 strategy. The five members of the Reggio Calabria Unit are: Francesco Bonsinetto (project coordinator), Angelo Cannizzaro, Enzo Falco, Barbara Lino and Giuseppe Modica.

\section{References}

ARNELL, N., W., LOWE, J., A., BROWN, S., GOSLING, S., N., GOTTSCHALK, P., HINKEL, J., LLOYD-HUGHES, B., NICHOLLS, R., J., OSBORN, T., J., OSBORNE, T., M., ROSE, G., A., SMITH, P., WARREN, R. F. (2013), A global assessment of the effects of climate policy on the impacts of climate change, Nature Climate Change, 3, pp. 512-519.

BARNOSKY, A. D., HADLY, E. A., BASCOMPTE, J., BERLOW, E. L., BROWN, J. H., FORTELIUS, M., GETZ, W., M., HARTE, J., HASTINGS, A., MARQUET, P., A., MARTINEZ, N., D., MOOERS, A., ROOPNARINE, P., VERMEIJ, G., WILlIAMS, J. W., GILLESPIE, R., KITZES, J., MARSHALL, C., MATZKE, N., MINDELL, D., P., REVILLA, E., SMITH, A., B. (2012), Approaching a state shift in Earth's biosphere, Nature, 486, pp. 52-58.

BOSSELMANN, K., BROWN, P., G., MACKEY, B. (2012), Enabling a Flourishing Earth: Challenges for the Green Economy, Opportunities for Global Governance, Review of European Community \& International Environmental Law, 21, 1, pp. 23-30.

BROCK, W., A., TAYLOR, M., S. (2005), Economic Growth and the Environment: A Review of Theory and Empirics, in: Aghion, P.; Durlauf, S. (ed.), Handbook of Economic Growth, edition 1, 1, chapter 28, pp. 1749-1821.

BUDD, L. (2013), Europe 2020: a strategy in search of a regional policy rationale?, Policy Studies, 34, 3, pp. 274-290.

BUTTER, F., A., G., VERBRUGGEN, H. (1994), Measuring the trade-off between economic growth and a clean environment, Environmental and Resource Economics, 4, 2, pp. 187-208.

COMMITTEE OF THE REGIONS (2012), The European urban fabric in the $21^{\text {st }}$ 
century, Proceedings of the 5th European Summit of Regions and Cities, 22-23 March 2012, Copenhagen.

DALY, H., E. (1997), Beyond growth: the economics of sustainable development, Beacon Press, Boston.

DALY, H., E., TOWNSEND, K., N. (1993), Valuing the earth. Economics, Ecology,

Ethics, MIT Press, Cambridge MA.

EDWARDS, A., R. (2010), Thriving Beyond Sustainability: Pathways to a Resilient

Society, New Society Publishers, Gabriola Island.

ESPON Atlas (2013), Territorial Dimensions of the Europe 2020 Strategy, June 2013.

ESPON Climate (2011), Climate Change and Territorial Effects on Regions and Local

Economies in Europe, Final Report, Espon Programme, Luxemburg.

ESPON Siesta (2013), Spatial Indicators for a "Europe 2020 Strategy Territorial Analy-

sis", Scientific Report 2013, Espon 2013 Programme, Luxemburg.

EUROPEAN COMMISSION (2009), EU White Paper "Adapting to climate change:

Towards a European framework for action", [COM/2009/0147 final]. EUROPEAN COMMISSION (2010a), Energy 2020. A strategy for competitive, sustainable and secure energy, [COM(2010) 639/3 final].

EUROPEAN COMMISSION (2010b), A strategy for smart, sustainable and inclusive growth, [COM(2010) 2020 final].

EUROPEAN COMMISSION (2010c), An integrated industrial policy for the globalisation

era. Putting competitiveness and sustainability at centre stage, [COM(2010) 614].

EUROPEAN COMMISSION (2011a), Renewable Energy: progressing towards the 2020 target, [COM(2011) 31 final].

EUROPEAN COMMISSION (2011b), Annual Growth Survey: advancing the EU's comprehensive response to the crisis, [COM(2011) 11 final].

EWEA (2011), EU Energy Policy to 2050. Achieving $80-95 \%$ emissions reductions, A

Report by the European Wind Energy Association. March 2011.

HOPWOOD, B., MELLOR, M., O'BRIEN, G. (2005), Sustainable Development. Mapping

Different Approaches, Sustainable Development, 13, 1, pp. 38-52.

IEA (2011), Co-Generation and Renewables: Solutions for a Low-Carbon Energy Future, available at: http://www.iea.org/papers/2011/CHP_Renewables.pdf.

IEA Report (2012), Medium-Term Renewable Energy Market Report 2012. Market Trends and Projections to 2017. OECD/IEA.

IPCC (2007a), Climate Change 2007: Mitigation of Climate Change. Contribution of Working Group III to the Fourth Assessment Report of the Intergovernmental Panel on Climate Change, UNEP/WMO.

IPCC (2007b), Climate Change 2007: Synthesis Report, Fourth Assessment Report (Workings Group I, II, III), UNEP/WMO.

KHOR, M. (2011), Risks and uses of the green economy concept in the context of sustainable development, poverty and equity, South Centre Research, Paper 40.

KINGTON, T. (2012), Italian town fighting for its life over polluting Ilva stee/works, The Guardian, 17 August 2012, available at: http://www.theguardian.com/world/2012/aug/17/italyilva-steelworks-cancer-pollution.

KOK, W. (2004), Facing the Challenge: The Lisbon Strategy for Growth and Employment, European Commission. High Level Group.

LATOUCHE, S. (2004), Survivre au développement: De la décolonisation de l'imaginaire économique à la construction d'une société alternative, Mille et une nuits, Paris.

LOORBACH, D. (2010), Transition Management for Sustainable Development: A Prescriptive, Complexity-Based Governance Framework, Governance: An International Journal of Policy, Administration, and Institutions, 23, 1, pp. 161-183.

MAKOWER, J., PIKE, C. (2009), Strategies for the green economy: opportunities and 
challenges in the new world of business, McGraw-Hill, New York.

MEADOWS, D., MEADOWS, D., RANDERS, J. (1992), Beyond the Limits, Earthscan

Publications, London.

MEICHTRY, S. (2012), A Chokehold Choice in Italy's South, The Wall Street Journal

Europe, 12 July 2012, available online at: http://online.wsj.com/news/articles/ SB10001424127887323316804578163570969783636.

MEYER, S., M. (1995), The Economic Impact of Environmental Regulation, Journal of

Environmental Law \& Practice, 3, 2, pp. 4-15.

OECD (2009), Declaration on Green Growth adopted at the Meeting of the Council at Ministerial Level on 25 June 2009, [C/MIN(2009)5/ADD1/FINAL].

PEARCE, D., MARKANDYA, A., BARBIER, E. (1989), Blueprint for a Green Economy, Earthscan Publications, London.

PLOEG Van Der, R., WITHAGEN, C. (2013), Green Growth, Green Paradox and the

Global Economic Crisis, Environmental Innovation and Societal Transitions, 6, pp. 116-119.

REGISTER, R. (2006), EcoCities. Rebuilding Cities in Balance with Nature, New Society Publishers, Gabriola Island.

SAPIR, A. et al. (2003), An Agenda for a Growing Europe, Making the EU Economic System Deliver, Report of an Independent High-Level Study Group established on the initiative of the President of the European Commission.

SHARACHCHANDRA, M. L. (1991), Sustainable development: A critical review, World Development, 19, 6, pp. 607-621. London

STERN, N. (2006), Stern Review on the Economics of Climate Change, HM Treasury,

ULHOI, J. P., MADSEN, H. (1999), Sustainable Development and Sustainable Growth: Conceptual Plain or Points on a Conceptual Plain?, Proceedings of the 17th International Conference of the System Dynamics Society "Systems thinking for the next millennium", Wellington, New Zealand.

ULRICH, B. (2012), Green Economy - the Next Oxymoron? No Lessons Learned from

Failures of Implementing Sustainable Development, GAIA - Ecological Perspectives for Science and Society, 21, 1, pp. 28-32.

UNEP (2011), Towards a Green Economy: Pathways to Sustainable Development and Poverty Eradication. A Synthesis for Policy Makers, www.unep.org/greeneconomy.

WHITEHEAD, M. (2007), Spaces of sustainability: geographical perspectives on the sustainable society, Taylor \& Francis, London.

ZGAJEWSKI, T., HAJJAR K. (2005), The Lisbon Strategy: Which Failure? Whose

Failure? And Why?, Egmont Paper 6, Royal Institute for International Relations, Brussels.

ZYSMAN, J., HUBERTY, M. (2012), From Religion to Reality. Energy systems transformation for sustainable prosperity, Working Papers BRIE Berkeley Roundtable on the International Economy

Initial submission: 27.05.2013

Revised submission: 29.08.2013

Final acceptance: 29.11.2013

Correspondence: Universita Mediterranea di Reggio Calabria, via Salita Melissari - 89124

Reggio Calabria - CF 80006510806, Italy.

E-mail: francesco.bonsinetto@unirc.it 